\title{
X-linked Alport syndrome-diffuse leiomyomatosis
}

INSERM

\section{Source}

INSERM. (1999). Orphanet: an online rare disease and orphan drug data base. X-linked Alport syndrome-diffuse leiomyomatosis. ORPHA:1018

The association of X-linked Alport syndrome with leiomyomatosis of the esophagus, tracheobronchial tree or female genitals has been reported in more than 30 families. 